\author{
Andrzej Citadysz \\ Jadwiga Kowalska \\ Instytut Muzykologii, Katolicki Uniwersytet Lubelski Jana Pawła II
}

\title{
Krakowskie spojrzenie na polską muzykę organową okresu Wielkiego Postu
}

W 2017 roku ukazała się pierwsza płyta nowej serii Cantate Domino in laetitia (z łac. „Śpiewajcie Panu z weselem”) przygotowana przez pracowników i studentów Międzyuczelnianego Instytutu Muzyki Kościelnej w Krakowie, zawierająca rejestracje dwóch cykli mszalnych francuskich kompozytorów: Charlesa Gounoda oraz Marcela Duruflé1.

Po dwóch latach oczekiwania seria wzbogaciła się o kolejne wydawnictwo, tym razem poświęcone solowej muzyce organowej Wielkiego Postu. Należy w tym miejscu zaznaczyć, że nagranie jest pokłosiem konferencji naukowej o wspomnianej tematyce, zorganizowanej przez Międzyuczelniany Instytut Muzyki Kościelnej w Krakowie oraz Katedrę Muzyki Religijnej tamtejszej Akademii Muzycznej. Warto również nadmienić, że Wydawcy nawiązali swoją płytą do półwiecza wydania Instrukcji wykonawczej Soboru Watykańskiego II „Musicam Sacram” oraz przyjęcia przez Konferencję Episkopatu Polski zaktualizowanej Instrukcji o muzyce kościelnej².

Wspomniane okazje stały się doskonałą kanwą dla przedstawienia wielopokoleniowego dorobku polskiej organistyki. Kierownictwo nad projektem objęli obecny prorektor ds. studenckich i dydaktyki ks. dr hab. Robert Tyrała, prof. UPJPII oraz dr hab. Witold Zalewski, dyrektor MIMK w Krakowie³. Wśród wy-

1 M. Mastyło, Międzyuczelniany Instytut Muzyki Kościelnej na niwie koncertowej i wydawniczej, „Vita Academica” 2017 nr 3 (92), s. 69.

2 W. Zalewski, Cantate Domino in laetitia II. Solowa muzyka organowa Wielkiego Postu, Kraków 2018, s. 5 (folder płyty CD).

3 Należy w tym miejscu podkreślić, że działalność kompozytorska i artystyczna polskich muzyków kościelnych żywo interesuje obu Profesorów, czego dowód stanowią prowadzone badania i publikacje będące ich pokłosiem (np. R. Tyrała, Cecyliański ruch odnowy muzyki kościelnej na ziemiach polskich do 1939 roku, Kraków 2010; W. Zalewski, Polska twórczość organowa zainspirowana pieśnia kościelna w liturgii Kościota rzymskokatolickiego, cz. I, „Pro Musica Sacra” 12 (2014), s. 169-199), które niewątpliwie wpłynęły na dobór repertuaru przedstawionego na recenzowanym krążku. 
konawców znaleźli się pracownicy, absolwenci i studenci MIMK: Maciej Banek, Maria Barcewicz, Wojciech Buda, Krzysztof Dobosz, s. Susi Ferfoglia, Marcin Gawęda, Mikołaj Kowalcze, Krzysztof Latała, s. Sylwia Marciniak, Jakub Mazurek, Krzysztof Michałek, Marcin Miotelka, Marek Pawełek, Michał Piechnik, Damian Sowa, Tomasz Ślusarczyk, Aksel Tulicki, Adam Zając, Karol Zwierniak. A zatem u boku mistrzów zaprezentowali się ich uczniowie, będący na różnych etapach swojego artystycznego rozwoju.

Mimo tak licznej i zróżnicowanej pod względem doświadczenia grupy wykonawców nagrania prezentują wysoki, solidny poziom. Szczególnie ciekawe i wartościowe są preludia: Gorzkie żale Stanisława Moniuszki (nr 1), Jezu Chryste, Panie mity ks. Franciszka Walczyńskiego (nr 5), Krzyżu święty Józefa Furmanika (nr 9), Ogrodzie oliwny Zdzisława Nowackiego (nr 10) i O krwi najdroższa Krzysztofa Grzeszczaka (nr 20) oraz chorał Ach, mój Jezu Feliksa Rączkowskiego (nr 8). Koniecznie należy zwrócić uwagę na improwizacje Tomasza Kalisza na tematy Rozmyślajmy dziś (nr 14) i Matko Najświętsza (nr 15) oraz fantazję Święty Boże Mariana Sawy (nr 18).

Odnosząc się do kwestii rejestracji i zaproponowanej palety brzmień, jakie możemy usłyszeć, zapoznając się z kolejnymi nagraniami, trzeba stwierdzić, że $\mathrm{w}$ wielu utworach są one do siebie zbliżone, co może powodować wrażenie monotonii, zwłaszcza w mniej efektownym repertuarze ${ }^{4}$. Jakkolwiek sama muzyka wielkopostna ma charakter wyciszony i medytacyjny, co wiąże się z oczywistymi ograniczeniami w zakresie wolumenu i bogactwa środków brzmieniowych, choć pojawiają się propozycje bardziej wyraziste, na przykład Suplikacja w opracowaniu Władysława Żeleńskiego oraz Mariana Sawy (ta druga nadałaby się zresztą doskonale na finałowy utwór) czy preludium Krzyżu Święty, nade wszystko tegoż kompozytora.

Powyższe wskazówki prowadzą do konstatacji, że dla pełnego zaprezentowania możliwości brzmieniowych czterdziestojednogłosowych organów o trakturze mechanicznej, wybudowanych przez Zakłady Organowe Zych z Wołomina w kościele Matki Bożej Ostrobramskiej Ojców Pijarów w Krakowie warto byłoby je pokazać w bardziej zróżnicowanym repertuarze. Można się tego zapewne spodziewać, skoro przedstawiony materiał został zrealizowany przy osobistym zaangażowaniu gospodarza parafii, o. Andrzeja Tupka.

4 Z całą pewnością nie ułatwił tego wymagający harmonogram nagrań, który zrealizowano zaledwie w ciągu trzech dni, między 23 a 25 października 2017 roku, a zatem w dwa tygodnie po poświęceniu organów przez bp. Jana Zająca (8 października 2017 roku), www. musicamsacram.pl/instrumenty/opis/2702-Krakow-Kosciol-Matki-Bozej-Ostrobramskiej (30.06.2019). 
Trudno ocenić, czy to przypadłość pojedynczej płyty, czy wada nagrania, ale dostrzeżone zostały pojedyncze stuknięcia (raczej niewynikające z techniki gry, na przykład w nr. 4 i 10). Nie sposób stwierdzić również, jakie jest źródło niespodziewanych zmian głośności (nr 6) - czy zamierzone, czy może będące efektem pracy realizatora dźwięku'.

Inicjatorzy wydawnictwa postanowili podkreślić związki muzyki organowej z pieśniami. We wstępie zwrócono uwagę na powstanie pierwszych śpiewników kościelnych w XIX wieku (ks. Michała Marcina Mioduszewskiego, Teofila Klonowskiego i ks. Jana Siedleckiego) oraz ich wpływ na popularyzację repertuaru wielkopostnego w muzyce instrumentalnej. Warto także dodać, że poza nagraniami wszystkie zarejestrowane utwory zostały zwięźle scharakteryzowane, z uwypukleniem najważniejszych - w ocenie autorów - aspektów historycznych, kompozytorskich czy też stylistycznych ${ }^{6}$. Można natomiast spierać się, czy właściwym zabiegiem jest wyeksponowanie na okładce tytułu serii wobec zupełnego pominięcia nazwy własnej konkretnego numeru wydawnictwa (Solowa muzyka organowa Wielkiego Postu). Dobór koloru fioletowego do oprawy graficznej okładki, płyty i fontu w dołączonej książeczce wyraźnie koresponduje z tym ważnym dla katolików okresem?

Utwory na płycie zostały zaprezentowane, co do zasady, w porządku chronologicznym. Dwa początkowe utwory napisane zostały przez Stanisława Moniuszkę na przełomie wileńskiego i warszawskiego okresu jego życia ${ }^{8}$. Kolejna pozycja to najciekawsze, jak się zdaje, z 25 Preludiów na organy op. 38 Władysława Żeleńskiego, będących efektem jego wieloletnich studiów z kontrapunktu i organów w Krakowie, Pradze i Paryżu oraz doświadczeń zawodowych z pracy w Krakowie i Warszawie, a zarazem doskonałego podręcznika gry na organach (i fisharmonii) ${ }^{9}$.

5 W całości nagranie prezentuje się solidnie, choć oczywiście w pełni można się nim delektować dopiero przy użyciu dobrej jakości nagłośnienia, pozwalającego wychwycić cenne niuanse kompozytorskie i wykonawcze. Realizatorem był Jakub Garbacz z Ars Sonora Studio.

6 W. Zalewski, Cantate Domino in laetitia II, s. 5-12.

7 Projekt graficzny opracował Antek Korzeniowski.

8 Warto zaznaczyć, że płyta uprzedziła obchody dwóchsetlecia urodzin kompozytora pochodzącego z Ubieli i ukazała jego niebagatelny dorobek w zakresie muzyki kościelnej. Świadczą o tym także inne wydawnictwa, jak na przykład Pieśni religijne czy Śpiewnik kościelny (E. Dziębowska, K. Duszyk, Moniuszko Stanistaw, w: Encyklopedia Muzyczna PWM. Część biograficzna, t. 6, red. E. Dziębowska, Kraków 2000, s. 303-335).

9 Zbiór doczekał się wielu edycji wydawniczych na różne instrumenty. Natomiast po raz pierwszy w całości został nagrany przez Julię Smykowską: Władysław Żeleński, Organ Preludes, Acte Préable 0007, Kamionka 1998. Rejestracji dokonano na organach Josepha Go- 
Na płycie znalazły się również trzy preludia ks. Franciszka Walczyńskiego, cenionego kompozytora muzyki religijnej związanego z tarnowską katedrą ${ }^{10}$, które podobnie jak u poprzednika pomyślano jako dzieła do wykonania przez „zwykłych" organistów.

W dalszej kolejności możemy usłyszeć preludia twórców mniej znanych, jak choćby wybitnego dyrygenta chóralnego i profesora oraz dyrektora Konserwatorium Muzycznego w Krakowie, Bolesława Wallek-Walewskiego ${ }^{11}$, nieznanego niemal zupełnie Zdzisława Nowackiego czy też pochodzącego z Zaolzia pedagoga i organisty Jana Gawlasa ${ }^{12}$. Przeplatają się one z kompozycjami wpływowych mistrzów, takich jak Feliks Rączkowski ${ }^{13}$ i Mieczysław Surzyński ${ }^{14}$.

Całości dopełniają nowoczesne aranżacje krakowskiego organisty i pedagoga Tadeusza Machla ${ }^{15}$, związanego ze stolicą nauczyciela i kompozytora Mariana Sawy ${ }^{16}$ oraz Tomasza Kalisza i Krzysztofa Grzeszczaka.

Nie sposób także nie dostrzec, że prezentowany zbiór zawiera pełen przekrój chronologiczny dzieł rodzimych kompozytorów tworzących od II połowy XIX wieku do współczesności. Repertuar bardzo zróżnicowany pod względem przynależności państwowej jego autorów prezentuje zwłaszcza w kontekście okresu niewoli i odzyskania niepodległości w 1918 roku, ukazując kompozycje z terenu wszystkich trzech zaborów, a zatem obrazujące niejednorodne drogi rozwoju polskiej kultury i odmienne traktowanie muzyki w liturgii. Widoczne jest także zróżnicowanie pod względem walorów artystycznych poszczególnych dzieł, zarówno konstrukcyjnych, jak i warsztatowych.

ebla z 1927 roku w kościele pw. Wszystkich Świętych w Poznaniu. Zob. J. Kukla, Dyspozycja organów Josepha Goebla w Archikatedrze Oliwskiej jako odzwierciedlenie XX-wiecznych nurtów w europejskiej muzyce organowej, „Aspekty Muzyki” 7 (2017), s. 267-268.

10 S. Garnczarski, Ks. Franciszek Walczyński - tarnowski kompozytor muzyki religijnej, „Tarnowskie Studia Teologiczne” 21 (2002), nr 1-2, s. 331-348.

11 J. Miklaszewska, Wallek-Walewski Bolestaw, w: Encyklopedia Muzyczna PWM. Część biograficzna, t. 12, red. E. Dziębowska, Kraków 2012, s. 58-59.

12 J. Habela, Gawlas Jan, w: Encyklopedia Muzyczna PWM. Część biograficzna, t. 3, red.

E. Dziębowska, Kraków 1987, s. 249.

13 J. Zathey, Raczkowski Feliks, w: Encyklopedia Muzyczna PWM. Część biograficzna, t. 8, red. E. Dziębowska, Kraków 2004, s. 326.

14 B. Chmara-Żaczkiewicz, Surzyński Mieczystaw, w: Encyklopedia Muzyczna PWM. Część biograficzna, t. 10, red. E. Dziębowska, Kraków 2007, s. 200.

15 A. Jarzębska, Machl Tadeusz, w: Encyklopedia Muzyczna PWM. Część biograficzna, t. 6, red. E. Dziębowska, Kraków 2000, s. 5-8.

16 M. T. Łukaszewski, Sawa Marian, w: Almanach Kompozytorów Akademii Muzycznej im. Fryderyka Chopina w Warszawie, t. 2, red. A. Gronau-Osińska, Warszawa 2004, s. 131-200. 
Doskonałym przykładem bogactwa opracowań jest pieśń Jezu Chryste, Panie mity, najliczniej reprezentowana na płycie. Ta pieśń pasyjna pochodzi z XVII wieku. Autorstwo tekstu przypisuje się Abrahamowi Rożniatowskiemu (niewykluczone, że ułożył go podczas przygotowywania dla oo. bernardynów scenariusza misterium Pamiątka Krwawej ofiary Pana Zbawiciela naszego Jezusa Chrystusa. Wedle miejsc Hierozolimskich nad Zebrzydowicami wykonfrektowanych). Melodię podał Mioduszewski w swoim śpiewniku ${ }^{17}$, a w niniejszej edycji została ona zaprezentowana kolejno w aranżacjach ks. Franciszka Walczyńskiego (nr 5), Bronisława Wallek-Walewskiego (nr 7), Mieczysława Surzyńskiego (w dwóch wersjach nr 11 i 12) oraz Jana Gawlasa (nr 13).

Różnorodne interpretacje zaprezentowano również w przypadku staropolskiej pieśni błagalnej Święty Boże $e^{18}$ - znajdują się tu kompozycje Władysława Żeleńskiego (nr 3) oraz Mariana Sawy (nr 18) oraz renesansowej pieśni pasyjnej Krzyżu Święty, nade wszystko - utwory Józefa Furmanika (nr 9) i Mariana Sawy (nr 17).

Z przyjemnością można komplementować aranżacje współczesne, nie tylko uznanego Mariana Sawy, lecz również kompozytorów młodszego pokolenia - Tomasza Kalisza i Krzysztofa Grzeszczaka - które znakomicie wypadają na tle opracowań nestorów polskiej szkoły organistowskiej.

Jeden z najważniejszych badaczy polskiej muzyki religijnej, ks. prof. dr hab. Ireneusz Pawlak, analizując rolę i zadania muzyki liturgicznej po Soborze Watykańskim II notował:

Więcej miejsca w liturgii powinno się przeznaczyć na wykonywanie muzyki organowej. Myślimy o utworach zarówno dawnych, jak i współczesnych mistrzów. Utwór organowy powinien być dostosowany do charakteru samego obrzędu, jak i długości jego trwania. (...) Trzeba przy tym zauważyć, że należące do dawnej muzyki utwory o przeznaczeniu liturgicznym posiadały zazwyczaj wymiary odpowiadające ramom czasowym danego obrzędu. (...) W praktyce liturgicznej cecha ta zawsze miała ważne znaczenie ${ }^{19}$.

Zapoznając się z drugą płytą serii Cantate Domino in laetitia poświęconą solowej muzyce organowej Wielkiego Postu, możemy być spokojni o piękno instrumentalnej oprawy muzycznej liturgii tego wyjątkowego okresu.

17 J. Siedlecki, Śpiewnik kościelny, wyd. 41, Kraków 2017, s. 190.

18 J. Siedlecki, Śpiewnik kościelny, s. 892-893.

19 I. Pawlak, Muzyka liturgiczna po Soborze Watykańskim II w świetle dokumentów Kościota, Lublin 2000, s. 220. Zob. także: J. Erdman, Możliwości wykorzystania literatury organowej we wspótczesnej liturgii, w: Muzyka sakralna, red. J. Masłowska, Warszawa 1998, s. 25. 